\title{
HUMANITIES
}

\section{THE ISSUE OF THE RELIGIOUS DIMENSION OF HUMAN NATURE}

\author{
Jan Mazur \\ Prof. PhD, Pontifical University of John Paul II in Kraków, \\ e-mail: jm.osppe@wp.pl, http://orcid.org/0000-0002- 0548-0205, Poland \\ Abraham Kome \\ PhD, John Paul II International University of Bafang, \\ e-mail: k_abra2006@yahoo.fr, orcid.org/0000-0001-7326-227X, Cameroon
}

\begin{abstract}
This text is an attempt to answer the question of whether human nature needs religion. The author begins by presenting two concepts that are key in this discourse. These are the terms: religion and human nature. Then he undertakes an analysis of the problem, referring to the thoughts of religious experts: Rudolf Otto and Mircea Eliade and the philosopher Max Scheler. The subject of reflection is the definition of man as 'homo religiosus'.

Questioning God's existence has a negative effect on human nature. This situation is illustrated by the views of two known philosophers, existentialists - Friedrich Nietzsche and Jean-Paul Sartre. Their vision of the world was marked by unbelief in God.

Life experience teaches that human nature strives for transcendent reality, longs for God. Any departure from this tendency does not, however, invalidate the religious nature of man, but certainly falsifies it. It results in the conversion of an authentic sacrum into its substitutes.

In conclusion, the author draws attention to the mystery of man and God, which should be recognized. It is only in this perspective that the problem indicated in the title can be considered. The inspiration for such thinking is the famous phrase of Saint Augustine of Hippo: 'The human soul is restless until it rests in God'.
\end{abstract}

Keywords: religion, human nature, integral anthropology, homo religiosus, sacrum, Rudolf Otto, Mircea Eliade, Max Scheler.

DOI: http://dx.doi.org/10.23856/3705

\section{Introduction}

The humanities or theological sciences still raise question marks regarding the sense and significance of the religious dimension of human nature. However, life experience in the history of humanity leaves no significant doubts in this respect. The fact of human religiosity is a common phenomenon. However, when undertaking a discourse on this subject, it is worth starting by pointing to the appropriate grid of concepts. It is necessary to avoid possible misunderstandings. This grid will be recalled in the area of language used by integral 
anthropology as well as religious studies. It is an integrated language due to the interdisciplinary nature of the issue. It finds application primarily in Christian personalism.

\section{Religion and human nature}

Due to the topic adopted in this text, one must first realize what religion is. According to the Theological Dictionary, under the redaction of Father Andrzej Zuberbier, religion means the whole of personal experiences and attitudes as well as socio-cultural events and structures, expressing in different ways the relationship of man's dependence on transcendent, supernatural reality. Of course, this is about the attitude towards God, or - as religologists or religionists generally maintain - to $\mathrm{S}$ (s) acrum, and philosophers of religion - to the Absolute (Łydka, 1998: 497-502).

The Great Encyclopedia PWN gives a concise, but relatively holistic approach to religion, taking a historical perspective. It comes from nominal definitions, which translate the term religion. And so Cicero derives the concept of religion from the Latin word relegare (read again), which essentially means the ability to read what is associated with God. Lactantius points to the Latin word religare (to bind again), which in turn expresses man's relationship with God. St. Augustine of Hippo associates the meaning of religion with the Latin reeligare (choose again). By this I mean choosing God as an object of worship. In nonEuropean traditions, religion is usually understood as the inviolable and sacred law of believers. The supernatural nature of this law requires them to adopt an appropriate spiritual attitude (Bronk, 2004: 240-243).

Whatever the case, religion generally appears as a relation of man to variously understood holiness, to the sacred (sacrum), to the sphere belonging to God (gods), manifesting in the doctrinal dimension (faith), in religious activities (worship), in the socioorganizational field (Church, religious community) and within individual religiosity (e.g. mysticism). The relationship between man and God (or sacrum) implies the activity of a human person experiencing a sense of holiness. This feeling manifests itself in experiencing the desire to get closer to the sacred, unite with it, and is also expressed in an attitude of worship, distance, and even fear of it (taboo). Thanks to religious experience, the sphere of the sacred penetrates the world of everyday life and manifests itself to man in a specific place and time (hierophania). There is an opinion among religious scholars that the religious experience of man is the basic phenomenon supporting the existence of religion.

Well, taking up the issue of religion, its essence, sense, genesis and meaning for man, it should be noted that this reality can not be completely explained by either empirical sciences about religion, due to methodological limitations, nor philosophical sciences, or even theological sciences. The subject of religion, however, is God (Transcendent Being, Absolute), who does not submit to scientific experience in the strict sense. Difficulties also appear in relation to man as the subject of a religious act. In a sense, religion remains a mystery both for science and for man himself. However, being also a socio-cultural fact, it becomes the subject of empirical research. It is almost obvious that a kind of religious experience has its definite impact on human life. Religion allows man to find in it the answers to the most fundamental existential questions. It constitutes a significant dimension of human life, covering all areas of human existence. It provides insight into the deepest foundations of being and existence as well as the purpose and purpose of man. In a word, religion seems to define human nature. 
The expression "human nature" in the most general and philosophical sense also means a set of constitutive features that determine the identity of man as a human being. However as Karol Wojtyła rightly maintains, with time, Pope John Paul II, in his work Person and Deed - human nature is not something abstract, but it always belongs to a specific person and is expressed in it. It is the basis of this person's existence and action. This nature implies the need for development through human activity. He becomes more and more himself when he works. One can speak of the value of human nature. In personalistic aspect, it should be recognized that culture is closely related to human nature (Wojtyta, 1969).

For culture means everything that man perfects and develops the talents of his spirit and body, and thus strives to make his land subjected by thought, will and work (cf. Gen 1:28). In particular, culture makes social life in the family and in the entire state community more human by improving customs and institutions. Finally, culture coupled with nature is expressed in the works that man creates, as well as in the spiritual experience that man retains and transmits.

From a Christian point of view, the nature of every being, and therefore also of man, comes from God. Human nature contains the potential and direction of its development, which is multidimensional and multifaceted. It concerns bodily, mental, spiritual, religious and cultural life.

Man is a person created by God. Moreover, he is "made in the image of God, he is like God" (Gen 1:26). He has the rational nature that God has given him and the tasks God sets for him. To fulfill these tasks and achieve their goals it is necessary to properly understand your own nature. If a person does not understand his place in God's creative and saving plan, then his misunderstanding can harm, and usually harms, his own good and even the good of others.

Human nature is stretched between what is visible, material, earthly and what is invisible, spiritual and supernatural. Man is a spiritual and bodily being endowed with dignity, i.e. a unique value, unique, shrouded in God's mystery. This being consists of an immaterial soul and a material body, which could be expressed in a different way: man is body and soul, or he is a spiritual body and an embodied spirit. This kind of shot could be multiplied. At this point it is worth stopping at the statement of St. Thomas Aquinas, according to which man is the substantive (subjective) unification of the immaterial soul and material body. Thanks to the effort of the spirit, he is able to transcend the material world, combining both these elements, spiritual and material, expressing his nature.

It should be noted, however, that on the grounds of personalism still nothing loses its transparency of the traditional approach of the person-person as an individual, independent, rational and substantive being, as the famous Boecius (Latin: Anicius Manlius Severinus Boethius), a Roman philosopher and politician from the late $\mathrm{V}$ and at the beginning of the sixth century, he summarized in a lapidary statement: persona est naturae rationalis individua substantia (Valverde, 1998: 41). So a person is an "indivisible or individual substance of a rational nature" or "individual substance of a rational nature". This definition, proposed by Boethius, was defended and explained by Saint. Thomas Aquinas, thanks to which she was accepted almost universally by Christian thinkers.

A man who is a rational being is involved in religion. This raises the question of whether there is a necessary relationship between a religion or religious attitude of a man and his rational nature that defines him as a person? 


\section{Man and his religious nature}

When looking for the answer to the question about the relationship between religion and human nature, it is worth considering the thesis of the famous German thinker Rudolf Otto (1869-1937). He spoke about religion as a philosopher, representative of phenomenology, as well as a Protestant theologian and religious expert. He proposed a descriptive definition of man using the term ens religiosum. In this approach, man appears as a religious being. The relationship with the sacrum (God) is the basic dimension of man. However, the experience of the sacred, possible to indicate only by means of ideograms or interpretative concepts, has its irreducible factors: mysterium tremendum (elements of horror, majesty, power and mystery) and mysterium fascinans (elements of delight, love, grace and salvation) (Otto, 1993).

Mircea Eliade (1907-1986), a famous Romanian religious expert, religion historian and cultural philosopher, introduced the term homo religiosus. He adopted the concept according to which man is a religious being, whose objective correlate is the existence of the sacred - the irreducible nucleus of all religious phenomena. He treated religion itself in an antireductionist, anti-evolutionist and holistic way (Eliade, 1997).

A similar view was presented by Max Scheler (1874-1928), a German philosopher and representative of phenomenology. According to his thoughts, man interprets his being in the world as homo religiosus. The human experience of God (sacred, divinity) is also an anthropological event. The religious phenomenon should be considered one of the important ways of self-realization of the human person in both the individual and social sphere.

However, the man perceived by Scheler is not only homo religiosus, but also a microcosm or even microtheos. There is a clear reference to Thales of Miletus (died around 545 B.C.), who is credited with the opinion that man is a microcosm. The word "microcosm" could be translated as "small world" or "small universe". This means that man is a specific image of the cosmos. When analyzing this term, it should be noted immediately that it does not contain any ontological depth. Tales just wanted to say that the same chemical elements as in space are found in humans, namely: solids (e.g. iron, calcium), liquids (e.g. hydrochloric acid) or gases (e.g. oxygen, hydrogen) (Mazur, 2014: 27).

A much deeper understanding of man as a microcosm brought Christian thought. For example St. Hildegard of Bingen (1098-1179), a Benedictine mystic, proclaimed by Pope Benedict XVI a doctor of the Church, used this expression to emphasize that man is a picture of the world and carries the secret of the universe. The whole world was created in the Word the Son of God who became Man. More contemporary writers, such as the aforementioned Max Scheler or Russian thinker Mikołaj Bierdiajew (1874-1948), will refer to this thought in time. In their view, man is not only a picture of the universe (microcosm), but also a picture of God, which they expressed with the Greek term microtheos (little God, God in diminution). Anyway, the term microtheos appeared already in the Christian Middle Ages as a necessary complement to the truth contained in the ancient term: microcosm (Mazur, 2014: 27-28).

Max Scheler, referring to the concept of homo religiosus, tried to present an integral vision of man that would fully correspond with his nature. Therefore, he also used or rather primarily the term: ens amans (loving being). In this definition, the emphasis falls on the "heart", and thus the emotional sphere (emotions) and aspirations, desires (will), which means "compassion with the heart" (co-experiencing and co-suffering). In this perspective, Scheler's often quoted sentences should be interpreted: "The one who loves precedes the one who has 
known", "Nothing is known, which is not loved before" or "A man is happy only when he loves and gives something, because he it is happiness to give than to take".

According to Scheller, human love for Ens a se, that is, to what exists in itself, is the foundation of humanity and becomes the spark of all spiritual acts of man, and above all personal love. Who is Ens a se? According to the intuition of a Christian man, this is not just some speculative philosophical construction. Ens a se simply means God or personal Sacrum, with which the relationship of love is the foundation of humanity. By the way, it is not difficult to notice that the idea of ens amans recalled in a sense coincides with the biblical mentality, according to which "knowing" means "to love", especially in the sense of love involving the sensual sphere (e.g. Gen 4, 1.4.25; Lk 1, 34) (Mazur, 2014: 35).

Man's relationship with God, especially the relationship of love, is something that could be described as the foundation of humanity, the foundation of human nature. However, it may turn out that this foundation is questioned, and man still functions even as a rational and social being (Aristotle) or an ethical being seeking himself (Socrates). In such a case, can human nature be non-religious, that is, may it not desire to enter into a relationship with transcendent reality?

\section{The secret of God and man}

To somehow solve the problem contained in the title of this text, it is impossible not to recognize that breaking a man's relationship with God is something that shocks human nature violently. It makes man become a tragic creature, full of contradictions. His existence raises a number of questions to which he does not find satisfactory answers. Two philosophers come to mind here, whose views seem to illustrate the situation of those who radically reject, deny or question the need for a relationship with God. One of them is Jean-Paul Sartre (1905-1980) - a leading French representative of atheistic existentialism, while the other is the famous Friedrich W. Nietzsche (1844-1900) - a German philosopher, prose writer and poet.

Sartre, who at one time in his life considered himself a nihilist, interpreted human life as absurd, senseless, tragic. His answer to the question of what it means to be a human being is already found in the very title of one of his books: Being and Nothingness. According to Sartre, the essence of man is that he has no being. In the novel bearing the highly eloquent title: Nausea expressed the thought of the randomness of human existence, which is absurdity. There is nothing that preceded and was the cause of existence. Randomness is at the heart of things. It makes the existence of the world make no sense. The tragedy of man lies in the fact that his life is futile, senseless (in French: non-sense).

According to Sartre, the fundamental existential experience of a human being is nausea, i.e. awareness of the absurdity of all things, while the highest manifestation of the absurdity of human life is death. Coexistence with other people does not give man any comfort, because these others are "hell" because they pose a threat to his freedom. However, man is tragic in his free "choices" because he can and must rely only on himself. He is in a way doomed to freedom, which means total independence and self-determination. Everyone must set his own values and truths. That is why freedom is like exile.

All in all, man is perceived as an "abandoned" being. He cannot find any support "within himself" (in French: En soi), because he has no human nature and rights, nor "outside himself" (in French: Pour soi), because, as Sartre tried to prove, God does not exist. If according to Sartre - God existed, then man would not be free, because God would be for this freedom, just like another man - a threat (Mazur, 2014: 113-116). 
In conclusion, one must admit that man in Sartre's thought is a tragic being. An element of the structure or nature of man as a tragic creature is the fear that people run from, creating myths (human rights, best practices, moral norms). As you can see, this is a vision of a man full of pessimism and nihilism, referring to absurdity and meaninglessness. His existentialism denying God's existence has little to do with humanism. Rather, it is a negation of true humanism. It reflects the vision of man, which aptly seems to summarize the famous phrase of Sartre: "It is absurd that we were born and absurd that we will die" (Szewczyk, 2009: 42). His words can also be synthesized by his words: "We are alone and nothing will justify us (...). Freedom is exile and I am doomed to freedom. I am free for nothing. Not a single sign in heaven or on earth" (Sartre, 1958).

It is strange that until recently European and American youth, especially students of philosophy, read the works of Sartre with great attention. They were treated as a kind of Bible. It did not bother them that their master was not only a philosopher, an atheistic existentialist, but also an ardent supporter of Marxism, as well as its Chinese version - Maoism.

Fortunately, absurdity is something foreign to human nature against which she defends herself. Therefore, preaching absurdity, as if subconsciously seeking liberation from absurdity. It seems that at the end of his life he reached his goal, but on a completely different path that he probably had never even thought of before. At the end of his life, when he lost his sight, he was looked after by his secretary - Benny Lévy, a practicing follower of Judaism. In this regard, there were suggestions that before his death, Sartre, which he was increasingly afraid of, approached Judaism. Nevertheless, in one of his first posthumous biographies there was information that just before leaving for eternity he reconciled with the Catholic Church. He was to proceed to the sacrament of penance and reconciliation. This information has not been included in subsequent editions of this biography.

In turn, Nietzsche saw man as a being full of contradictions. According to his thoughts, human life is an instinct, a will to power (desire to control others), contempt for the truth or the dominance of one people's morality over others. Nietzsche, being a tamer of all principles of truth and goodness, postulated that people evolve to create a superman. He imagined him as a free being (liberated from the values adopted by the masses) and as a creator (he creates all values himself, including good and evil) and the legislator (he creates the law for the human "flock" of which he is the master and tyrant). This superman is proud, brave, towering over the crowd, resistant to all suffering. He also defeats death because he is a creature accepting the repetition of the entire history of the world (according to the idea of eternal return taken from Greek mythology) (Nietzsche, 1907).

In order for a "superman" to arise out of man, he must - according to Nietzsche - "die God," because the idea of God was created by people, thereby humiliating themselves. This precursor of the "death of God" theology, built the philosophy of human loneliness. It is associated with "joyful knowledge" that "God has died, God is dead" (Nietzsche, 1910). The proclamation of God's death was made in the name of humanism, which suggests the necessity of choosing between God and man. Since God does not exist, he could not propose the meaning of human life. The absence of God is associated with the absence of absolute values: good, truth and holiness (nihilism). These assumptions allowed Nietzsche to formulate a "desperate", pessimistic program of life, affirming the nonsense: "To live in such a way that there is no sense in living" (Nietzsche, 1907: 61).

Nietzsche firmly rejected hope as the basis of human happiness. He even regretted the fact that many people live with the hope of happiness, because - in his opinion - it is in fact the greatest evil, because it only prolongs human suffering. Strongly rejecting Christianity, he 
believed in the cyclical existence of the world, namely, he assumed that what was already there is still reborn. Only "eternal return" can ensure "superman" victory over death. He spoke of "tragic wisdom", which is an apotheosis of existence, but leads to the rejection of both pessimism and optimism. In his opinion, tragedy is an experience of "the pleasure of becoming", which also causes suffering.

Analyzing Nietzsche's thought, one needs to be aware that from his youth he had mental health problems. This fact did not prevent, however, that his philosophical views inspired and inspire many philosophers, writers, publicists and even politicians, something borrowed by the ideology of the superman by Hitler's ideology. His way of thinking can easily be found in many modern humanists. Therefore, the question arises: why did this kind of human vision manage to have a huge impact on people's mentality? It can be said that in a sense the Nietzsche age came, based on the assumption of "God's death". It consists in exaggerating what is instinctive, sensual over what is Christian. Nietzsche's phenomenon is wonderfully reflected and at the same time as if they are explaining his own words: "I am the first immoralist and thus the destroyer par excellence" (Nietzsche, 1996:127).

In the end, however, Nietzsche admitted that without God man falls into loneliness. $\mathrm{He}$ complained about the lack of friends, the longing for someone close to him. Announcing the death of God, at the same time he called him, as evidenced by his famous song of "killed God": "Oh no. Return again with all your torments. / To the last of the loners. Oh come back, come. / All sources of my tears flow to you after all. / My heart's last flame - ignited you. / Come back, come. Unknown my God. My pain My last happiness!" (Nietzsche, 1901: 356).

Do the thinkers mentioned above, Sartre and Nietzsche, confirm the thesis about the religious nature of man? Existentialism, marked by disbelief in God, proved completely useless to them. Finally, they both longed for God whom they tried to erase from their consciousness. Intellectual arguments and justifications were of no avail, since their human nature proved stronger than the claims of rebellious reason.

Man, denying the existence of God, questioning the relationship with Him, cannot fully realize his humanity, because his nature seems to lose his life orientation, he is deprived of a sense of meaning. In order to save his existential situation, man desperately looks for some substitute for God. Nature hates a vacuum. Man, throwing God out of his heart, must fill them with something or someone else. Experience shows that this substitute plays the role of a sacred, regardless of the intentions of a man burdened with God's negation or distance from religion. And so in the case of Sartre's faith in God, the relationship with God was replaced by hopeless, nonsense Freedom, marked by absurdity and leading into nothingness. In Nietzsche, the role of the sacred was played by the idea of a superman, while faith in the fulfillment of this idea grew to the rank of beliefs that show a striking resemblance to religious beliefs.

All in all, it can be concluded that every departure from faith in God, as it were out of necessity, resulting from human nature, must be filled with something. I need some substitute. This is clearly seen in the example of people immersed in atheistic ideologies. Was Marxism a kind of carbon copy of Christianity? Was he not trying to replace Christianity, becoming for many of his followers a "religion" with his own beliefs ("scientific" socialism based on dialectical materialism), worship (e.g. monuments, May Day marches, academies in honor of the communist revolution) and an organizational structure (system party pursuing the ideological dictatorship of the proletariat)?

It is no different for people in Neo-Marxism today. Ideologies that fit into the so-called Cultural Marxism has many faces. One of them is genderism or its particular manifestation in the form of elbiebetism. For atheists or people identifying themselves as religiously 
indifferent, this is an offer that they willingly accept, regardless of their sexual identity. It is a substitute for religion for them. In this respect, the LGBT movement has already created its distinctive features resembling the elements of religion, namely: the doctrine in the form of beliefs (e.g. the idea of cultural sex falsifying the truth about biological sex), worship (e.g. marches of "equality" or "gay" and "pride" marches) and organizational structures (strong homosexual lobby in media and politics). There is only a lack of faith in the personal sacrum, but in extreme cases there is a nod to personal evil, which in turn takes the form of Satanism. Why does human nature cling to transcendent reality, yearns for God, induces man to cross himself in the direction of the sacrum? Departing from this natural tendency does not yet cancel the religious nature of man, but certainly falsifies it. It results in the conversion of an authentic sacrum into its substitutes, so dangerous for the man himself.

\section{Attempt to conclude}

The above remarks address a problem that cannot be unequivocally resolved based on scientific or popular science discourse. It belongs to the sphere which refers to the sacred. You can say a whole series of sentences about the religious nature of man, which, however, are part of a broader conclusion. Her most basic thesis could be formulated as follows: man is a secret to himself. At this point, Saint. Augustine of Hippo (354-430), bishop and doctor of the Church, who made the thesis as a definition of man. In total, he defines man as a creature thirsting for God, which perfectly captures even his thought: "You created us [God] as directed towards You and our heart is restless until it rests in You" (Św. Augustyn, 1994:75) (Tenże, Wyznania, p. 75).

According to St. Augustine, a man yearns for God, whom he seeks with all his heart, after all he can be realized only in love. After all, God is love (cf. $1 \mathrm{Jn} 4$ : 8, 16). Love of God is love of the truth and leads to knowing the truth, which gives man joy. Why is this happening? Bishop Hippony explains that man is a rational soul using a mortal and earthly body, with the soul being defined as a rational substance adapted to direct the body. After all, the human soul is a place where God lives. Therefore, the mystery of man can be explored only in the light of God, who - in the thought of St. Augustine - is the highest principle of human existence, absolute perfection, the only apartment of truth, the source of all human knowledge, the beginning, model and end of every human being. In this perspective, the words of Bishop Hippo contained in his immortal work De civitate Dei (Lord of God) are not surprising: "A great thing, man, because God made him in his own image, but man remains a mystery to himself" (Szewczyk, 2009: 26).

The mystery of man inscribed in his nature seems to reveal and explain the problem of man's relationship with God. It is a necessary and mysterious relationship, because it also concerns the mystery of God. Finally, you can only for St. Augustine, conclude that human nature is restless until he rests in God, i.e. he does not enter into a full relationship with Him.

\section{References}

Bronk, A. (2004). Religia, in: Wielka Encyklopedia, Vol. 23. Warszawa: PWN 2004, P. 240243. [in Polish].

Eliade, M. (1997). W poszukiwaniu historii i znaczenia religii. Grzybek, A. (Trans.). Warszawa: Wydawnictwo KR. [in Polish]. Jan Pawet II. (1980). Encyklika Redemptor 
hominis, in: Redemptor hominis - tekst i komentarz. Kraków: Polskie Towarzystwo Teologiczne, P. 3-62. [in Polish].

Kowalczyk, S. (1983). Człowiek jako mikrokosmos i mikrotheos. Gość Niedzielny, 60 (5), 4-5. [in Polish].

Krapiec, M. A. (2006). Osoba, in: Powszechna Encyklopedia Filozofii, Maryniarczyk, A. (Ed.), Vol. 7, Lublin: Polskie Towarzystwo św. Tomasza z Akwinu, P. 873-887. [in Polish].

Kunka, S. (2013). Osoba ludzka i natura człowieka. Personalistyczne ujęcie natury człowieka wg Karola Wojtyly. [Electronic resource]. Retrieved from https://idmjp2.pl/index.php /pl/wydarzenia/prelekcje/415-wyklad-otwarty-osoba-ludzka-i-natura-czlowieka. [in Polish].

Kurdziałek, M. (1969). Koncepcje człowieka jako mikrokosmosu, in: Bejze, B. (Ed.). O Bogu i o człowieku: problemy filozoficzne, Vol. 2. Warszawa: Wydawnictwo Sióstr Loretanek, P. 109-125. [in Polish].

Leśniak, K., Tales z Miletu. Warszawa: PWN. [Electronic resource]. Retrieved from http://www.wiw.pl/filozofia/filozofowie/tales_z_miletu. [in Polish].

Łydka, W. (1998). Religia, in: Stownik Teologiczny. (Ed.). Zuberbier, A. Katowice: Księgarnia Św. Jacka, P. 497-503. [in Polish].

Mazur, J., OSPPE. (2014). Persona in societate. Wybrane zagadnienia chrześcijańskiej nauki o człowieku. Kraków: Wydawnictwo Naukowe UPJPII. [in Polish].

Misiaczek, K. (2000). Czym jest religia? [Electronic resource]. Retrieved from https://opoka.org.pl/biblioteka/K/wam/spotkania-3-1.html. [in Polish].

Nietzsche, F. (1901). Tak mówił Zaratustra. Cumft, M., Pieńkowski, S. (Trans.). Warszawa: Wydawnictwo Władysława Okręta. [in Polish].

Nietzsche, F. (1907). Antychryst. Przemiany wszystkich wartości. Staff, L. (Trans.). Warszawa: Nakład Jakóba Mortkowicza. [in Polish].

Nietzsche, F. (1910). Wiedza radosna. Staff, L. (Trans.). Warszawa: wyd. J. Mortkowicz. [in Polish].

Nietzsche, F. (1996). Ecce homo. Jak się staje, kim się jest. Baran, B. (Trans.). Kraków: Wydawnictwo Baran i Suszczyński. [in Polish].

Olszewski, D. (1988). Z zagadnień religioznawstwa. Łódź: Diecezjalne Wydawnictwo Łódzkie. [in Polish].

Otto, R. (1993). Świętość: elementy irracjonalne $w$ pojęciu bóstwa $i$ ich stosunek do elementów racjonalnych. Kupis, B. (Trans.). Wrocław: Thesaurus Press. [in Polish].

Piętka, R. (2009). Mikro- i makrokosmos w starożytności - od presokratyków do Ojców Kościoła, in: Makrokosmos versus Mikrokosmos. Magowska, A. (Ed.). Poznań: Wydawnictwo Poznańskiego Towarzystwa przyjaciót nauk "Kontekst”. [in Polish].

Safranski, R. (2003). Nietzsche. Biografia myśli. Stroińska, D. (Trans.). Warszawa: Wyd. Czytelnik. [in Polish].

Sartre, J.-P. (1958). Drogi wolności. Zwłoka, Vol. 2. Rogoziński, J. (Trans.). Warszawa: PIW. [in Polish].

Scheler, M. (1987). Pisma z antropologii filozoficznej i teorii wiedzy. Wegrzecki, A. (Trans.). Warszawa: Państwowe Wydawnictwo Naukowe. [in Polish].

Św. Augustyn. (1930-1934-1937). Państwo Boże. Kubicki, W. (Trans.). Poznań: Wydawnictwo Poznańskie. [in Polish]. 